Volume 10. Nomor 1. June 2015
Pandecta
http://journal.unnes.ac.id/nju/index.php/pandecta

\title{
Tingkat Partisipasi Masyarakat dalam Menggunakan Hak Suara pada Pemilu Legislatif 2014
}

\author{
Muhammad Bayu Dwi Cahyo
}

Fakultas Hukum Universitas Negeri Semarang, Indonesia

Permalink/DOI http://dx.doi.org/10.15294/pandecta.v9i1.

\begin{tabular}{l} 
Info Artikel \\
\hline Sejarah Artikel: \\
Diterima November2014 \\
Disetujui December 2014 \\
Dipublikasikan January 2015 \\
\hline Keywords: \\
Participation, legislative elec- \\
tions, abstention.
\end{tabular}

Abstrak

Partisipasi masyarakat dalam pemilihan umum, merupakan salah satu parameter dari kemajuan demokrasi. Penelitian ini bertujuan untuk menganalisis partisipasi masyarakat dalam pemilihan umum tahun 2014 dengan mengambil studi kasus di Kecamatan Godong, Kabupaten Grobogan. Hasil penelitian menunjukkan bahwa Tingkat Partisipasi Masyarakat dalam Menggunakan Hak Suara dalam Pemilu Legislatif 2014 di Kecamatan Godong Kabupaten Grobogan meningkat di bandingkan pada Pemilu Legislatif 2009, dari $67 \%$ menjadi $69 \%$. Dalam memilih suatu Parpol masyarakat memilih bukan karena fanatik pada suatu Parpol, akan tetapi karena melihat dari prestasi dan kinerja dari tokoh-tokoh atau anggota yang berada pada suatu Parpol. Tingginya masyarakat urban di Kecamatan Godong juga menjadi penyebab tingginya angka golput. Golput Merupakan hak asasi manusia, tetapi jika masyarakat tidak dapat memilih karena tidak terdatar sebagai DPT (Daftar Pemilih Tetap) merupakan suatu pelanggaran HAM, karena telah menghilangkan hak politik sebagai warga Negara yang berhak untuk memilihSimpulan dari penelitian ini adalah tingkat partisipasi masyarakat dalam menggunakan hak suara dalam Pemilu Legislatif 2014 di Kecamatan Godong Kabupaten Grobogan sedikit meningkat jika dibandingkan dengan Pemilu Legislatif 2009.

\begin{abstract}
People participation in the generale election is a parameter of the democracy development. This research is intended to analyze the people participation in the 2014 election by taking case in the Godong subdistrict, Grobogan Regency, Central Jawva. The results showed that the rate of Public Participation in the Use of Voting Rights in the 2014 legislative elections in District Godong Grobogan this time slightly increased in comparison to the legislative elections in 2009, from $67 \%$ to $69 \%$. In choosing a political party because the people chose not fanatical on a political party, but as seen from the achievements and performance of the leaders or members who are in a political party. The high urban communities in the District Godong also be the cause of the high rate of abstention. An abstention human rights, but if the people can not vote because not registered as Permanent Voters List is a violation of human rights, as has removed political rights as citizens are entitled to vote. Conclusions of this study is the level of community participation in the use of voting rights in the 2014 legislative elections in District Godong Grobogan slightly increased when compared to the 2009 legislative elections.
\end{abstract}




\section{Pendahuluan}

Di Indonesia Pemilu merupakan pesta demokrasi yang diadakan setiap lima tahun sekali untuk memilih wakil rakyat secara langsung anggota lembaga negara, yaitu DPR, DPD dan DPRD serta Presiden dan Wakil Presiden. Dalam Pemilu, masyarakat memilih secara bebas yang berarti masyarakat harus memilih sesuai dengan hati nurani dan tanpa paksaan dari siapapun. Menurut anggota Badan Pengawas Pemilu (Bawaslu) Nur Hidayat Sardini mengenai format idealitas Pemilu 2014, Pemilu bukan hanya persoalan teknis. Demokrasi tanpa Pemilu adalah omong-kosong. Pemilu akan pincang jika mengesampingkan demokrasi. Kualitas pemilu ditentukan mekanisme dan tata prosedur.

Dalam Pasal 1 ayat (2) UUD 1945 menyatakan bahwa rakyat memiliki kekuasaan (kedaulatan) yang tertinggi. Mekanisme terhadap penyerahan kedaulatan rakyat ini, akan dilakukan melalui wakilnya (representative democracy) adalah melalui Pemilu. Pemilu yang baik adalah pemilu yang dilaksanakan sesuai dengan tata cara dan prosedur yang berlaku dan dijalankan dengan jujur (Janedjri, 2012).

Sejak tahun 1955 hingga 2009 bangsa Indonesia telah melaksanakan 10 kali pemilihan umum legislatif. Akan tetapi dalam setiap pelaksanaannya masih banyak masyarakat yang tidak menggunakan hak suara mereka dalam pemilu tersebut. Bahkan dalam setiap Pemilu masyarakat yang tidak menggunakan hak suaranya cenderung meningkat.

Istilah golput atau golongan putih sesungguhnya sudah ada pada sejak pemilu di massa orde baru. Dan fenomena golput tersebut semakin meluas, tidak hanya mengancam pada Pemilu tingkat nasional tetapi juga hingga tingkat pemilukada. Berbagai upaya telah dilakukan dalam menekan angka golput hingga adanya penerapan fatwa haram pada golput. Isltilah golput sendiri pertama kali muncul menjelang Pemilu 1971. Istilah ini sengaja dimunculkan oleh Arief Budiman dan kawan-kawannya sebagai bentuk perlawanan terhadap pemerintah dan ABRI yang pada saat itu secara sepenuhnya memberikan dukungan politis mereka kepada partai
Golkar. Arogansi tersebut dianggap menyimpang dari kaidah demokrasi, dimana kekuasaan sepenuhnya ada ditangan rakyat yang memilih.

Golput adalah hak kontitusional bagi setiap pemilih untuk tidak menggunakan hak suaranya pada pemilu, yang dilindungi UUD 1945 Pasal 28E ayat (2): setiap orang berhak atas kebebasan meyakini kepercayaan, menyatakan pikiran dan sikap, sesuai dengan hati nuraninya.

Ada perbedaan antara golput pada massa orde baru dengan golput pada massa reformasi. Pada massa orde baru golput dilakukan sebagai bentuk perlawanan terhadap arogansi pemerintah dan ABRI. Sedangkan pada era reformasi, golput merupakan bentuk dari fenomena dalam demokrasi.

Sesuai dengan sejarahnya bahwa golput adalah sebuah bentuk gerakan perlawanan terhadap penguasa. Perlawanan tersebut biasa karena alasan apatis terhadap penguasa, penyelenggara pemilu dan hal-hal lain yang berkaitan dengan pemilu yang tidak mementingkan kehendak rakyat yang sesungguhnya.

Banyak kalangan yang menyimpulkan, karena tingginya angka golput pada setiap Pemilu maka pemenang yang sebenarnya pada Pemilu sebenarnya adalah golput, bukan partai politik, cagub, caleg atau yang lainnya. Meskipun demikian golput bukan untuk kemenangan politik. Golput hanya bentuk ketidak puasan masyarakat terhadap penyelenggaraan pemilu sehingga sebesar apapun angka golput tersebut tetap tidak bisa berkuasa.

Pada era reformasi ada berbagai macam penyebab golput diantaranya, karena masyarakat yang mau memilih namun tidak terdaftar, masyarakat yang tidak mau memilih namun terdaftar, serta masyarakat yang tidak mau memilih dan tidak terdaftar. Ada beberapa daerah di Indonesia yang memiliki jumlah golput yang tinggi pada saat Pemilu. Bahkan jumlah golput tersebut melebihi jumlah suara yang masuk pada saat Pemilu. Salah satunya adalah di Kecamatan Godong Kabupaten Grobogan.

Tingginya angka golput pada setiap penyelenggaraan Pemilu menjadi permasala- 
han yang sulit teratasi pada setiap penyelenggaraan Pemilu. Bahkan Ada beberapa daerah yang tingkat partisipasi masyarakat terhadap Pemilu khususnya Pemilu Legislatif bisa dibilang masih rendah. Salah satunya adalah di Kecamatan Godong Kabupaten Grobogan. Kecamatan Godong menjadi salah satu kecamatan dengan angka golput tertinggi di Kabupaten Grobogan.

Pada Pemilukada Jateng 2013 jumlah angka golput di Kecamatan Godong Kabupaten Grobogan sangatlah tinggi. Berdasarkan data dari quick count atau penghitungan cepat dari total suara yang terdaftar dalam daftar pemilih tetap seluruh desa di Kecamatan Godong sebesar 66.499 pemilih, ada sebanyak 37.870 (56,95\%) pemilih tidak hadir, sementara pemilih yang hadir sebanyak 28.629 $(43,05 \%)$ pemilih. Bahkan ada salah satu desa di Kecamatan Godong yaitu Desa Tugu dimana pemilih yang hadir hanya sebesar $27,96 \%$. Hal ini menunjukkan bahwa tingkat partisipasi masyarakat dalam mengikuti pemilu di Kecamatan Godong masih sangatlah rendah. (Sumber : KPU Kabupaten Grobogan).

Tidak seperti pada Pilgub 2013, pada Pemilu legislatif 2014 yang baru saja selesai, dari sebesar 66.378 pemilih, ada sebanyak 45.564 (69\%) pemilih yang hadir, sementara pemilih yang tidak hadir sebanyak 21.743 (31\%) pemilih yang tidak hadir. Menurut Bapak Sarsono sebagai ketua PPK Kecamatan Godong, salah satu faktor warga memilih untuk tidak hadir pada Pemilu dikarenakan banyak warga yang menjadi perantau. Baik merantau keluar kota maupun menjadi TKI diluar negeri. (Sumber : KPU Kabupaten Grobogan)

Berdasarkan uraian di atas, penulis berhasil mengkaji tentang tingkat partisipasi masyarakat dalam menggunkan hak suara dalam pemilu legislatif di kecamatan Godong kabupaten Grobogan. Tiga persoalan yang akan dianalisis dalam paper ini adalah: Pertama adalah tentang bagaimana tingkat partisipasi masyarakat dalam menggunakan hak suara dalam pemilu legislatif 2014 di Kecamatan Godong Kabupaten Grobogan. Kedua adalah tentang mengapa masyarakat di Kecamatan godong melakukan golput dan bagaimana pula solusinya. Ketiga tentang bagaimana ketentuan hukum mengenai golput menurut UUD 1945.

\section{Metode Penelitian}

Penelitian yang akan dilakukan oleh penulis menggunakan metode penelitian kualitatif. Penelitian kualitatif menurut Moleong (2005:6) adalah "penelitian yang bermaksud untuk memahami fenomena tentang apa yang dialami oleh subjek penelitian misalnya perilaku, persepsi, motifasi, tindakan dll, secara historic, dan dengan cara deskripsi dalam bentuk kata-kata dan bahasa, pada suatu konteks khusus yang alamiah dan dengan memanfaatkan berbagai metode alami$a h^{\prime \prime}$. Pada penelitian ini menggunakan pendekatan penelitian Yuridis Sosiologis, Yuridis Sosiologis adalah penelitian hukum yang menggunakan data sekunder sebagai data awalnya, yang kemudian dilanjutkan dengan data primer atau data lapangan, Meneliti efektivitas suatu Undang-Undang dan Penelitian yang ingin mencari hubungan (korelasi) antara berbagai gejala atau variabel sebagai alat pengumpul datanya terdiri dari studi dokumen, pengamatan (observasi), dan wawancara (interview) (Amiruddin dan Asikin, Zainal. 2003; Adi, 2010).

Adapun sumber data utama dalam penelitian kualitatif adalah kata-kata dan tindakan yang selebihnya adalah data tambahan seperti dokumen dan lain-lain (Moleong, 2007:157). Sumber data merupakan masalah yang perlu diperhatikan dalam setiap penelitian ilmiah, agar diperoleh data yang lengkap, benar, dan dapat dipertanggungjawabkan. Ini meliputi data primer dan data sekunder. Sumber data utama atau primer yaitu katakata atau tindakan orang-orang yang diamati (Moleong, 2007: 57). Data sekunder sebagai pelengkap untuk melengkapi dan menyelesaikan data primer.

Teknik pengumpulan data yang digunakan yaitu dengan cara wawancara, dokumentasi. Wawancara adalah teknik pengumpulan data yang digunakan peneliti untuk mendapatkan keterangan-keterangan lisan melalui bercakap-cakap dan bertatap muka dengan orang yang dapat memberikan keterangan pada sipeneliti (Mardalis, 2010:64). 
Wawancara adalah cara pengumpulan data dengan jalan tanya-jawab sepihak yang dikerjakan dengan sistematik dan berlandaskan kepada tujuan penelitian (Marzuki, 2002:62). Dokumentasi merupakan salah satu cara untuk memperoleh data dan informasi yang berkaitan dengan pokok bahasan melalui dokumen-dokumen dan mengkaji bahan-bahan yang bersangkutan dengan masalah-masalah yang diteliti. Metode dokumentasi adalah menarik data mengenai hal-hal atau variable yang berupa catatan, transkip, buku, surat kabar, majalah, notulen, rapat, prasasti, agenda dan sebagainya (Arikunto, 2006:206).

Pengolahan dan Analisis data pada penelitian hukum sosiologis, tunduk pada cara analisis data ilmu-ilmu sosial. Untuk menganalisis data, tergantung pada sifat data yang dikumpulkan oleh peneliti (tahap pengumpulan data). Metode analisa data yang digunakan dalam penelitian ini adalah menggunakan metode pendekatan kualitatif, yaitu suatu pembahasan yang dilakukan dengan cara memadukan antara penelitian kepustakaan dan penelitian lapangan. Penelitian kepustakaan yang dilakukan adalah membandingkan peraturan-peraturan, ketentuanketentuan, dan buku referensi, serta data yang diperoleh, kemudian dianalisis secara kualitatif yang akan memberikan gambaran menyeluruh tentang aspek hukum yang berhubungan dengan masalah yang akan diteliti. (Amiruddin, 2012)

\section{Hasil Penelitian dan Pembahasan}

\section{Gambaran KPU Kabupaten Grobogan}

Komisi Pemilihan Umum Daerah yang selanjutnya disebut KPUD adalah KPU Provinsi, Kabupaten/Kota sebagaimana dimaksud dalam Undang -Undang Nomor 12 Tahun 2003 yang diberi wewenang khusus oleh undang-undang ini untuk menyelenggarakan pemilihan kepala daerah dan wakil kepala daerah di setiap provinsi dan/atau kabupaten/kota, sebagaimana diamanatkan dalam Pasal 1 Angka 21 UU Nomor 32 Tahun 2004 Tentang Pemerintah Daerah.
Tugas dan wewenang KPU Kabupaten/Kota dalam penyelenggaraan Pemilu Anggota Dewan Perwakilan Rakyat, Dewan Perwakilan Daerah, dan Dewan Perwakilan Rakyat Daerah meliputi: a) menjabarkan program dan melaksanakan anggaran serta menetapkan jadwal di kabupaten/kota; b) melaksanakan semua tahapan penyelenggaraan di kabupaten/ kota berdasarkan peraturan perundangundangan; c) membentuk PPK, PPS, dan KPPS dalam wilayah kerjanya; d) mengkoordinasikan dan mengendalikan tahapan penyelenggaraan oleh PPK, PPS, dan KPPS dalam wilayah kerjanya; e) Memutakhirkan data pemilih berdasarkan data kependudukan dan menetapkan data pemilih sebagai daftar pemilih; f) menyampaikan daftar pemilih kepada KPU Provinsi; g) menetapkan dan mengumumkan hasil rekapitulasi penghitungan suara Pemilu Anggota Dewan Perwakilan Rakyat Daerah Kabupaten/Kota berdasarkan hasil rekapitulasi penghitungan suara di PPK dengan membuat berita acara rekapitulasi suara dan sertifikat rekapitulasi suara; dan h) melakukan dan mengumumkan rekapitulasi hasil penghitungan suara Pemilu Anggota Dewan Perwakilan Rakyat, Anggota Dewan Perwakilan Daerah, dan Anggota Dewan Perwakilan Rakyat Daerah Provinsi di kabupaten/ kota yang bersangkutan berdasarkan berita acara hasil rekapitulasi penghitungan suara di PPK.

Selain itu, tugas dan wewenang KPU Kabupaten/Kota adalah a) membuat berita acara penghitungan suara serta membuat sertifikat penghitungan suara dan wajib menyerahkannya kepada saksi peserta Pemilu, Panwaslu Kabupaten/Kota, dan KPU Provinsi; b) menerbitkan keputusan KPU Kabupaten/Kota untuk mengesahkan hasil Pemilu Anggota Dewan Perwakilan Rakyat Daerah Kabupaten/ Kota dan mengumumkannya; c) mengumumkan calon anggota Dewan Perwakilan Rakyat Daerah Kabupaten/Kota terpilih sesuai dengan alokasi jumlah kursi setiap daerah pemilihan di kabupaten/ kota yang bersangkutan dan membuat 
berita acaranya; d) memeriksa pengaduan dan/atau laporan adanya pelanggaran kode etik yang dilakukan oleh PPK, PPS, dan KPPS; e) menindaklanjuti dengan segera temuan dan laporan yang disampaikan oleh Panwaslu Kabupaten/ Kota; f) Menonaktifkan sementara dan/ atau mengenakan sanksi administratif kepada anggota PPK, PPS, sekretaris KPU Kabupaten/Kota, dan pegawai sekretariat KPU Kabupaten/Kota yang terbukti melakukan tindakanyang mengakibatkan terganggunya tahapan penyelenggaraan Pemilu yang sedang berlangsung berdasarkan rekomendasi Panwaslu Kabupaten/Kota dan ketentuan peraturan perundang-undangan; g) melakukan evaluasi dan membuat laporan setiap tahapan penyelenggaraan Pemilu; dan h) melaksanakan tugas dan wewenang lain yang diberikan oleh KPU, KPU Propinsi, dan/ atau undang-undang.

Begitu pula halnya dengan KPU Kabupaten Grobogan yang mempunyai tugas untuk melaksanakan semua tahapan penyelenggaraan di kabupaten/ kota berdasarkan peraturan perundangundangan dan tugas-tugas lainnya seperti yang telah tertera diatas. KPU Kabupaten bertugas untuk mengadakan sosialisasi pemilu untuk menekan angka golput di Kabupaten Grobogan.

Pada periode ini, KPU Kabupaten Grobogan beralamat di Jl. S.Parman No.2 Purwodadi. KPU beranggotakan sebagai berikut: Afrosin Arif, S.Pd., M.H. (Ketua), Ir. Jati Purnomo, M. Si. (Divisi Sosialisasi), Sakta Abaway Sakan, S.Ag. (Divisi Tungsura), Siti Lailatul Fauziah, S.Ag. (Divisi Hukum), dan Saikur Rokhman, S. Pd. (Divisi Mutarlih).

Menurut Undang-Undang No. 22 Tahun 2007 Tentang Penyelenggaraan Pemilihan Umum, Sekretariat KPU Kabupaten/Kota bertugas membantu penyusunan program dan anggaran Pemilu, memberikan dukungan teknis administrative, membantu pelaksanaan tugas KPU Kabupaten/Kota dalam menyelenggarakan Pemilu, membantu pendistribusian perlengkapan penyelenggaraan Pemilu Anggota Dewan Perwakilan Rakyat, Dewan Perwakilan Daerah, dan Dewan Per- wakilan Rakyat Daerah, Pemilu Presiden dan Wakil Presiden, serta Pemilu Kepala Daerah dan Wakil Kepala Daerah Provinsi, membantu perumusan dan penyusunan rancangan keputusan KPU Kabupaten/Kota, memfasilitasi penyelesaian masalah dan sengketa Pemilu Kepala Daerah dan Wakil Kepala Daerah Kabupaten/Kota, membantu penyusunan laporan penyelenggaraan kegiatan dan pertanggungjawaban KPU Kabupaten/Kota; dan membantu pelaksanaan tugas-tugas lainnya sesuai dengan peraturan perundang-undangan.

\section{Gambaran Kecamatan Godong Kabupaten Grobogan}

Kecamatan Godong memiliki relief daerah pegunungan kapur dan perbukitan serta berada pada ketinggian sampai 50 meter di atas permukaan air laut dengan kelerengan $0^{\circ}-8^{\circ}$ Dilihat dari Peta Kabupaten Grobogan, Kecamatan Godong teletak di sebelah barat kota Purwodadi dan jarak antara kedua kota tersebut sekitar $18 \mathrm{Km}$. Adapun potensi di wilayah kecamatan ini meliputi hasil-hasil Pertanian, dan Peternakan dan juga aspek umum lainnya, serta wisata Api Abadi Mrapen (http://grobogan.go.id).

Godong (bahasa jawa), artinya daun. Menurut cerita tokoh masyarakat, pada abad 18 pada kekuasaan raja Mataram, dalam suatu pasowanan ada salah satu Adipati tidak hadir, maka sang Raja mengutus 2 putrinya, Mayangsari dan Mekarsari, yang dikawal seorang "Cantrik", "Kamdowo", untuk menanyakan ketidakhadiran Adipati. Ditengah perjalanan Cantrik gandrung (senang) dengan 2 Putri Raja dan dipaksa untuk menjadi istrinya. Sang Putri menolak, akhirnya sang Putri bunuh diri dan dimakamkan di bawah pohon yang daunnya rimbun (wit godong ketel) maka dinamakan Desa Godong.

Kecamatan Godong sebagaimana kecamatan lain di Grobogan terbentuk bersama-sama dengan terbentuknya Kabupaten Grobogan yaitu berdasarkan UU No. 13 Tahun 1950 tentang Pembentukan Daerah-daerah Kabupaten di lingkungan Propinsi Jawa Tengah.

Secara administratif Kecamatan Go- 
dong terdiri dari 28 Desa, 512 RT, dan 103 RW dengan ibukota berada di Desa Godong, dengan koordinat geografis $07^{\circ} 01^{\prime} 25^{\prime \prime} \mathrm{S}$ $110^{\circ} 46^{\prime} 23,1^{\prime \prime}$ E. Kecamatan ini mempunyai luas $86.78 \mathrm{Km}^{2}$ dengan jumlah penduduk pada keadaan Bulan Januari 2012 sebanyak 90.750 jiwa (http://grobogan.go.id/pemerintahan/kecamatan/kecamatan-godong-grobogan.html).

\section{Tingkat Partispasi Masyarakat dalam Menggunakan Hak Suara dalam Pemilu Legislatif 2014 di Kecamatan Godong Ka- bupaten Grobogan}

Indonesia merupakan negara yang menjunjung demokrasi sehingga dalam menentukan pemerintah baik itu anggota legislatif ataupun Presiden akan lewat cara Pemilihan Umum dan Pemilihan Legislatif. Pemilihan legislatif adalah pemilihan umum anggota Dewan Perwakilan Rakyat (DPR), Dewan Perwakilan Daerah (DPD), serta Dewan Perwakilan Rakyat Daerah (DPRD) yang nantinya akan bertugas menjadi anggota lembaga legislatif. Pemilihan legislatif diadakan setiap 5 tahun sekali.

Kecamatan Godong adalah salah satu kecamatan dengan angka golput tertinggi di Kabupaten Grobogan dari setiap penyelenggaraan pemilu. Seperti pada PILGUB 2013 ada sebanyak $37.870(56,95 \%)$ pemilih tidak hadir, sementara pemilih yang hadir hanya 28.629 (43,05\%) pemilih. Sedangkan pada Pemilu Legislatif sendiri, pada Pemilu Legislatif 2009 dari sebesar 63.488 pemilih, ada sebanyak $42.848(67,49 \%)$ pemilih yang hadir, sementara pemilih yang tidak hadir sebesar $20.640(32,51 \%)$ pemilih yang tidak hadir. 2014 kali ini dari sebesar 66.378 pemilih, ada sebanyak 45.564 (69\%) pemilih yang hadir, sementara pemilih yang tidak hadir sebesar 21.743 (31\%) pemilih yang tidak hadir. Tabel 1 menunjukkan daftar jumlah pemilih yang hadir pada Pileg 2014. Sedangkan Tabel 2 menunjukkan grafik pemilih yang hadir dan yang tidak hadir.

Tabel di atas menunjukan bahwa ting- kat golput di Kecamatan Godong Kabupaten Grobogan pada Pemilu Legislatif 2014 kali ini bisa di bilang meningkat. Walaupun secara presentase hampir sama, tetapi ada sedikit peningkatan jumlah pemilih yang hadir dari Pileg 2009 dengan Pileg 2014 kali ini. Itu menunjukan bahwa antusiasme masyarakat pada Pileg 2009 dan Pileg 2014 hampir sama, walaupun ada sedikit peningkatan dari pemilih yag hadir.

Angota Divisi Sosialisasi KPU Kabupaten Grobogan, Ir. Jati Purnomo, M. Si., menjelaskan sebagai berikut:

"Selain Kecamatan Karangrayung dan Kecamatan Penawangan, Kecamata Godong juga menjadi Kecamatan dengan tingkat golput tertinggi di Kabupaten Grobogan di setiap penyelenggaraan Pemilu..." (Wawancara tanggal 20 Juni 2014).

Dari keterangan tersebut, kemungkinan masalah yang menjadi penyebab tingginya angka golput di Kecamatan Godong adalah sama. Sebab dari beberapa penyelenggaraan pemilu, tiga Kecamatan tersebut memperoleh angka golput yang tertinggi di Kabupaten Grobogan.

Dalam penyelenggaraan pemilu pasti terdapat kendala-kendala yang didapatkan oleh KPU. Dalam wawancara penulis dengan Divisi Sosialisasi KPU Kabupaten Grobogan, yaitu Bapak Ir. Jati Purnomo, M. Si. megemukakan:

"Salah satu masalah yang menjadi kendala dalam penyelenggaraan pemilu di Kecamatan Godong adalah eksistensi domisili warga Godong, banyak warga yang merantau ke luar kota dan memiliki KTP di tempat mereka merantau akan tetapi masih terdaftar sebagai DPT di Kecamatan Godong..." (Wawancara, tanggal 20 Juni 2014).

KPU Kabupaten Grobogan juga telah melakukan upaya untuk meningkatkan tingkat partisipasi masyarakat dalam menggunakan hak suara dalam Pemilu Legislatif 2014 di Kecamatan Godong Kabupaten Grobogan. Dalam wawancara penulis dengan Divisi Sosialisasi KPU Kabupaten Grobogan, yaitu Bapak Ir. Jati Purnomo, M. Si. menyata- 
kan bahwa:

"KPU telah melakukan sosialisasi dengan tokoh ulama dan tokoh masyarakat untuk mengajak para warga untuk menggunakan hak suara mereka. KPU juga telah melakukan siaran keliling disetiap desa, penyebaran spanduk di masing-masing desa dan juga membuat iklan di radio dan media cetak di Grobogan..." (Wawancara, tanggal 20 Juni 2014).

Pada Pemilu Legislatif kali ini juga terjadi beberapa pelanggaran-pelanggaran. Jati Purnomo juga berpendapat bahwa pelanggaran-pelanggaran yang terjadi pada Pemilu Legislatif lalu berwujud antara lain banyaknya pemasangan alat peraga kampanye, seperti baliho, stiker, spanduk dan lain-lain yang melebihi jumlah dan tidak dipasang tidak pada tempatnya.

Selain itu, penulis juga telah melakukan investigasi tentang bagaimana tingkat partisipasi masyarakat dalam menggunakan hak suara dalam Pemilu Legislatif 2104 di Kecamatan Godong Kabupaten Grobogan kepada Duabelas (12) warga Kecamatan Godong yang memiliki hak suara dalam Pemilu Legislatif 2014.

Informan pertama yang berinisial HP, laki-laki beragama agama Islam, degan pendidikan terakhir SMP, dan lahir di Grobogan tahun 1987, dan tinggal di Desa Godong. Dia menyatakan,

"Kemarin saya ikut nyoblos, tapi saya agak bingung tata cara mencoblos, karena menurut saya sosialisasi dari KPU kurang, tapi saya antusias pada Pemilu Legislatif kali ini, walaupun hasilnya tidak sesuai dengan harapan saya. Menurut saya yang kurang pada Pemilu Legislatif kali ini adalah masih adanya politik uang. Harapan saya penjagaan terhadap pemunguta suara diperketat agar tidak di manipulasi..." (Wawancara, 26 Juni 1014).

Informan yang kedua, berinisial S, laki-laki beragama Islam, dengan pendidikan terakhir SMP, lahir di Grobogan pada tahun 1972, dan tinggal di Desa Bugel Rejomulyo. Tentang keikusterstaannya dalam Pemilu, dia menyatakan:
"Ya, kemarin saya menggunakan hak suara saya, dan saya tahu tata cara mencoblos, saya sangat antusias pada Pemilu Legislatif kali ini dan Alhamdulillah hasilnya sesuai dengan harapan saya. Menurut sya yang kurang dalam pemilu kali ini adalah pada panitianya mas. Ya harapan saya pada pemilu kali ini si pemilih tetap bersifat LUBER..." (Wawancara, tanggal 26 Juni 1014).

Informan ketiga, berinisial $\mathrm{M}$, laki-laki beragama Islam dengan pendidikan terakhir SD, serta lahir di Grobogan pada tahun 1964, dan tinggal di Desa Bugel. Dia mengemukakan sebagai berikut:

"Ya, kemarin saya ikut nyoblos mas dan saya tahu tentang cara mencoblos. Kalo soal ikut serta berpartisipasi dalam mengawasi pemilu sebenarnya saya tidak peduli, yang saya tahu yang penting saya nggak golput dan saya nggak begitu peduli pada hasil Pemilu Legislatif kali ini. Menurut saya yang kurang pada Pemilu Legislatif kali ini adalah masih banyak terjadi politik uang dan seperti dibiarkan sama panwaslu..." (Wawancara tanggal 26 Juni 1014).

Informan keempat, yang berinisial TIN, perempuan, beragama Islam, dengan pendidikan terakhir S1, serta lahir di Grobogan pada tahun 1992, dan tinggal di Desa Manggarmas. Dalam wawancara, dia mengemukakan:

"Sebenarnya saya nggak peduli dengan hasil Pemilu Legislatif kemarin mas, yang penting saya dating ke TPS dan ikut nyoblos, soal ada kecurangan atau lain-lainnya saya nggak mau tahu, ya harapan saya dapat pemimpin yang baik..." (Wawancara tanggal 26 Juni 1014).

Informan yang kelima berinisial HD, perempuan agama Islam, pendidikan terakhir SMA, lahir di Grobogan pada tahun 1983, beralamat di Jl. Suprapto Kecamatan Godong. Berikut hasil wawancaranya:

"Saya menggunakan hak pilih saya karena saya punya hak pilih. jadi saya harus menggunakannya dan saya tidak mau golput, karena saya ingin mendapat pemimpin 
yang lebih baik dan yang sesuai dengan apa yang diharapkan masyarakat..." (Wawancara tanggal 26 Juni 1014).

Informan keenam berinisial $\mathrm{AH}$, lakilaki agama Islam, pendidikan terakhir SMA, tempat tanggal lahir di Grobogan pada tahun 1983, beralamat di Desa Bugel Kecamatan Godong. Berikut hasil wawancaranya:

"Saya kemarin menggunakan hak suara saya mas, dan saya antusias pada Pemilu Legislatif kali ini. Menurut saya sosialisasi dari KPU sudah cukup dan saya saya senang dengan hasil pemilu kali ini karena sesuai dengan harapan saya. Kalo ada politik uang ya saya terima-terima saja itungitung rejeki mas dan anggep saja itu uang kenal dari caleg-nya..." (wawancara tanggal 26 Juni 1014).

Informan yang ketujuh, berinisial LRS, perempuan agama Islam, pendidikan terakhir SMA, lahir di Grobogan tahun 1992, beralamat di Desa Bugel Kecamatan Godong. Berikut hasil wawancaranya:

"Saya menggunakan hak suara saya mas, tapi saya tidak tahu hasilnya bagaimana karena jujur saya tidak antusias. Kalo tentang politik uang menurut saya itu suda mendarah daging dan selalu ada setiap pemilu, tapi saya biarkan saja karena percuma kalo lapor juga nggak ada penanganan..." (wawancara tanggal 26 Juni 1014).

Informan kedelapan, berinisial KR, laki-laki agama Islam, pendidikan terakhir S1, lahir di Grobogan pada tahun 1960, beralamat di Desa Godong Kecamatan Godong. Ia menyatakan sebagai berikut:

"Menurut saya masyarakat seharusnya juga ikut berperan dalam mengawasi pelaksanaan Pemilu, tidak hanya ikut mencoblos saja. Karena kecurangan-kecurangan pemilu itu terjadi kan didalam lingkungan masyarakat juga, jadi kalo masyarakat lepas tangan dengan pengawasan pemilu ya pelanggaran-pelanggaran akan terus ada..." (wawancara tanggal 26 Juni 1014).

Informan yang kesembilan, berinisial RF, laki-laki agama Islam, pendidikan terakhir S1, lahir di Grobogan pada tahun 1988, beralamat di Desa Godong Kecamatan Godong. Berikut hasil wawancaranya:

"Ya, saya menggunakan hak suara saya mas, kalo tentang hasilnya saya tidak tahu karena saya nggak ngikutin berita-beritanya jadi saya nggak tahu, yang penting kan saya sudah menggunakan hak suara saya dan tidak golput, kalo tentang yang lainlainnya saya nggak tahu..." (Wawancara tanggal 26 Juni 2014).

Informan kesepuluh, berinisial NY, perempuan agama Islam, pedidikan terakhir SD, lahir di Grobogan pada tahun 1967, beralamat di Desa Harjowinangun Kecamatan Godong. la mengemukakan pernyataan sebagai berikut:

"Saya tidak nyoblos, soalnya pas pemilu legislatif kemarin saya masih di Jakarta, nggak sempet pulang mas, lagian ongkos tiket bus sekarang mahal, sebenernya ya pengen nyoblos, tapi mau gimana lagi saya nggak bisa ninggal kerjaan di Jakarta, jadi saya lebih baik golput saja..." (wawancara tanggal 28 Juni 2014).

Informan yang kesebelas berinisial BS, laki-laki beragama Islam, pendidikan terakhir SMA, lahir di Grobogan tahun 1977, beralamat di Desa Harjowinangun Kecamatan Godong. Berikut hasil wawancaranya:

"Saya nggak ikut nyoblos kemarin mas, soalnya saya nggak tahu mau pilih apa, calegcaleg nya siapa aja saya juga tahu sama sekali, jadi saya nggak tertarik buat nyoblos, dari pada saya asal-asalan nyoblos nya ya mendingan saya nggak ikut nyoblos aja..." (wawancara tanggal 28 Juni 2014).

Informan keduabelas, berinisial MAF, laki-laki agama Islam, Pendidikan terakhir SMP, lahir di Grobogan pada tahun 1995, beralamat di Desa Harjowinangun Kecamatan Godong Kabupaten Grobogan. Berikut hasil wawancaranya:

"Saya nggak ikut nyoblos mas, saya belum tertarik buat ikut nyoblos, soalnya calegcalegnya nggak ada yang menarik, saya belum percaya sama caleg-caleg yang sekarang, paling entar ujung-ujungnya juga lupa sama rakyat mas..." (wawancara 
tanggal 28 Juni 2014).

Dari hasil wawancara tersebut dapat disimpulkan bahwa mayoritas masyarakat Kecamatan Godong Kabupaten Grobogan yang memiliki hak suara dan yang berada di Kecamatan Godong (tidak berada di luar kota), mereka tidak mengerti tentang pelanggaran-pelanggaran didalam Pemilu. Yang mereka tahu hanyalah datang ke TPS dan menggunakan hak suara mereka. Itu menggambarkan bahwa antusias mereka terhadap Pemilu masih kurang.

Ada beberapa macam bentuk partisipasi dengan tingkatan-tingkatannya. Menurut Milbrath dan Goel yang dikutip Sudijono Sastroatmodjo (1995 : 74-75) membedakan partisipasi menjadi beberapa kategori, yaitu Kategori pertama adalah apatis, yaitu orang yang menarik diri dari proses politik. Kedua adalah spektator. Kategori kedua ini berupa orang-orang yang setidak-tidaknya pernah ikut dalam pemilihan umum. Ketiga gladiator, yakni orang-orang yang secara aktif terlibat dalam proses politik, yakni sebagai komunikator dengan tugas khusus mengadakan kontak tatap muka, aktivis partai dan pekerja kampanye, serta aktivis masyarakat. Keempat pengkritik, yaitu orang-orang yang berpartisipasi dalam bentuk yang tidak konvensional.

Sedangkan menurut David F Roth dan Frank L. Wilson, melihat masyarakat terbagi dalam empat kategori: a. Aktivis (Activists), b. partisipan (Perticipants), c. Penonton (Onlookers), dan d. Apolitis (Apoliticals). Kategori Aktivis (Activists) terdiri dari pejabat publik atau calon pejabat publik, fungsionaris partai politik, pimpinan kelompok kepentingan. Selanjutnya Kategori partisipan (Perticipants) terdiri dari orang yang bekerja untuk kampanye, anggota partai secara aktif, partisipan aktif dalam kelompok kepentingan dan tindakan yang bersifat politis, dan orang yang terlibat dalam komunitas proyek. Penonton (Onlookers) terdiri dari orang yang menghadiri reli-reli politik, anggota dalam kelompok kepentingan, pe-lobby, pemilih, orang yang terlibat dalam diskusi politik, dan pemerhati dalam pembangunan politik. (Budiarjo, 2008: 372-372).
Dari kategori-kategori tingkat partisipasi diatas dapat digunakan untuk mengkategorika tingkat partisipasi masyarakat dalam menggunakan hak suaranya dalam Pemilu legislatif 2014 di Kecamatan Godong Kabupaten Grobogan. Dari penelitian yang dilakukan oleh penulis yang apatis atau menarik diri dari proses politik dengan tidak menggunakan hak suaranya pada penyelenggaraan Pemilu. Masih sedikit masyarakat yang benar-benar aktif dalam Pemilu, kebanyakan dari mereka hanya menjadi spektator ataupun hanya sebagai penonton (Onlookers).

\section{Alasan Masyarakat Kecamatan Godong Kabupaten Grobogan Melakukan Golput dan Solusinya.}

Untuk mengetahui alasan masyarakat Kecamatan Godong Kabupaten Grobogan melakukan golput, penulis melakukan wawancara dengan Anggota KPU Kabupaten Grobogan. Anggota KPU tersebut berpendapat:

"Yang menjadi penyebab golput salah satunya adalah masalah social masyarakat. Bahwa di Kecamatan Godong penduduk urbannya sangat tinggi, sekitar 25-30\% pemilih tidak berada ditempat melainkan berada di luar kota untuk bekerja maupun untuk kuliah di luar kota..." (wawancara tanggal 20 Juni 2014).

Banyaknya masyarakat Kecamatan Godong yang merantau ke luar menjadi salah satu penyebab tingginya angka golput. Keberadaan masyarakat yang jauh dari kampong halamannya yang dimana mereka terdaftar sebagai DPT adalah suatu kendala mengapa masyarakat enggan untuk hadir di TPS untuk menggunakan hak pilihnya dan mereka juga tidak dapat meninggalkan pekerjaan mereka di luar kota untuk mengikuti pemilihan umum. Selain itu rumitnya prosedur administrasi pindah memilih membuat masyarakat enggan untuk mengurusnya karena mereka sulit meninggalkan pekerjaan mereka untuk mengurus administrasi pindah memilih tersebut.

Tingkat golput juga tergantung oleh kesadaran dari masyarakat sendiri. Jika ke- 
sadaran masyarakat terhadap Pemilu sendiri rendah maka tingkat golput pun angka meningkat dan negitu pula sebaliknya. Maka dari itu sosialisasi tentang Pemilu harus lebih ditingkatkan agar kepedulian masyarakat mengenai Pemilu meningkat dan masyarakat mau untuk dating ke tempat pemungutan suara untuk menggunakan hak suaramya.

Dari tahun 2013 pihak KPU Grobogan telah melakukan sosialisasi dengan tokoh ulama dan tokoh masyarakat untuk mau mengajak warga untuk ikut serta dalam setiap pemilu. KPU Grobogan juga mengadakan sosialisasi disetiap tempat kerja, di tempat warga saat ada tahlilan-tahlilan di kampong dan juga saat ada perkumpulan ibu-ibu PKK. KPU Grobogan juga melakukan siaran keliling di setiap desa, melakukan penyebaran spanduk dan mengadakan iklan melalui radio maupun media cetak yang ada di Kabupaten Grobogan.

Berdasarkan hasil wawancara penulis dengan Bapak Ir. Jati Purnomo. Anggota Divisi Sosialisasi KPU Grobogan, dia menyatakan keterangan sebagai berikut:

"Menggunakan hak pilih itu tergantung kesadaran masyarakat nya, selain itu faktor ekonomi juga berpengaruh, karena banyaknya warga Kecamatan Godong yang menetap untuk bekerja dan kuliah di luar kota, membuat mereka enggan untuk pulang pada saat adanya Pemilu. Seharusnya proses pindah memilih itu dipermudah agar warga yang ada di luar kota tetap bisa memilih..." (wawancara tanggal 20 Juni 1992).

Dalam setiap penyelenggaraan Pemilu selalu tidak lepas dari pelanggaran-pelanggaran di dalam Pemilu. Berdasarkan hasil wawancara penulis, Bapak Ir. Jati Purnomo. Msi sebagai Divisi Sosialisasi KPU Grobogan menyatakan bahwa:

"Tentu saja ada pelanggaran-pelanggaran yang terjadi dalam setiap pemilu, dan kebanyakan pelanggaran yang sering ditemui yaitu seperti banyaknya pemasangan alat peraga kampanye seperti baliho, stiker, spanduk dan lain-lain yang melebihi jumlah dan tidak pada tempatnya..." (wawan- cara tanggal 20 Juni 2014).

Dalam mengatasi pelanggaran-pelanggaran dalam pemilu dibutuhkan juga partisipasi dari masyarakat dalam ikut mengawasi pelanggaran-pelanggaran yang terjadi. Dan dengan adanya peran masyarakat juga menggambarkan antisiasme masyarakat dalam penyelenggaraan pemilihan umum.

Jati Purnomo menyatakan bahwa dalam menekan angka golput, KPU Kabupaten Grobogan bekerjasama dengan Pemda untuk pemilih daerah di tingkat kecamatan. la juga mengatakan bahwa pemilu yang ideal adalah pemilu yang diikuti oleh parpol yang kredibel, penyelenggara yang berintegritas dan netral. Juga pemilih yang cerdas dan adanya aturan hukum yang memberikan kepastian hukum. Selanjutnya, Jati Purnomo juga menyatakan dalam wawancara bahwa dalam menelenggrakan pemilu yang ideal KPU harus bekerja sesuai dengan aturan hukum dan perpu dengan jujur, adil, transparan, professional, efektif, efisien dan akuntabel.

Hasil penelitian ini menunjukkan bahwa KPU Kabupaten Grobogan telah melakukan upaya-upaya dalam meningkatkan partisipasi masyarakat Kecamatan Godong dalam menggunakan hak suaranya dalam pemilu dengan mengadakan sosialisasi di setiap desa dan juga sosialisasi melalui iklan di radio dan di media cetak yang ada di kabupaten Grobogan. KPU Kabupaten Grobogan juga telah berupaya untuk menyelenggarakan pemilu yang ideal.

\section{Ketentuan Hukum Mengenai Golput Menurut UUD 1945}

Golput menjadi suatu permasalahan pada setiap penyelenggaraan Pemilu. Setiap masyrakat mempunyai alasan-alasan yang berbeda mengapa mereka menggunakan hak suara mereka dan megapa mereka memilih untuk Golput pada saat penyelenggaraan pemilu. Pemilihan umum (Pemilu) sendiri telah diatur didalam UUD 1945 sebagai produk hukum tertinggi di Negara kita. Akan tetapi hingga sekarang banyak masyarakat yang tidak peduli dengan Pemilu dan memilih untuk tidak menggunakan hak suaranya pada 
saat Pemilu diselenggarakan.

Ketentuan mengenai Pemilu dalam UUD 1945. Didalam setiap penyelenggaraan Pemilu seolah-olah tidak bisa lepas dari fenomena Golput, walaupun sebenarnya belum ada ketentuan hukum yang melarang adanya Golput. Seperti dijelaskan pada Undang-Undang Dasar (UUD) 1945 yang diamandemen tahun 1999-2002 Pasal 28 E yang berbunyi "Pemilihan umum dilaksanakan secara langsung, umum, bebas, rahasia, jujur, dan adil setiap lima tahun sekali". dari pasal tersebut sudah jelas dijelaskan bahwa tidak ada "kewajiban" bagi masyarakat untuk menggunakan hak pilih mereka, melainkan hanya ada kata "bebas" yang berarti masyarakat bebas untuk memilih ataupun tidak memilih.

Dari sudut hukum, jelas sekali kalau memilih dan dipilih adalah hak, demikian pula secara hak asasi. Hak untuk memilih merupakan hak perdata warga negara, demikian juga hak untuk berpendapat. Tidak ada hukum apa pun yang menyebutkan mereka yang memilih untuk tidak menggunakan hak pilihnya dalam Pemilu, akan dikenakan sanksi atau dikriminalkan oleh negara.

Secara hukum memang tidak ada satu kekuatan apa pun yang dapat menghalanghalangi seseorang untuk bersikap golput atau tidak menggunakan hak pilihnya. Namun bukan berarti pemerintah boleh membiarkan hal itu terjadi dan membiarkan angka golput semakin meningkat. Pemerintah juga harus berupaya untuk mengatasi fenomena golput tersebut agar pada saat penyelenggaraan $\mathrm{Pe}$ milu sendiri dapat berjalan dengan baik. Seperti, lebih meningkatkan sosialisasi tentang Pemilu dan lain-lain.

Memilih dan dipilih merupakan hak sipil politik. Sebagai hak, ia menghendaki jaminan kebebasan untuk menggunakan atau tidak menggunakannya. Memilih untuk memilih atau memilih untuk tidak memilih adalah pilihan dan pilihan adalah hak. Sebagian berpendapat Negara atau Pemerintah yang memaksa menggunakan atau memaksa tidak menggunakan hak mendasar itu, merupakan pelanggaran hak asasi manusia yang mendasar. Oleh karena itu, tindakan sebagian Warga Negara yang tidak menggunakan hak pilihnya apapun itu motifnya harus dihormati sebagai HAM warga Negara.

Penyebab masyarakat golput tidak hanya disebabkan karena kehendak masyarkat yang memilih untuk golput, akan tetapi juga karena masyarakat tidak dapat memilih dikarenakan tidak terdaftar sebagai daftar pemilih tetap (DPT) yang dapat menghalangi keinginan masyarakat untuk menggunakan hak suara mereka dalam Pemilu. Hal tersebut juga merupakan suatu pelanggaran HAM, karena telah menghilangkan hak politik sebagai warga Negara untuk dapat memilih pada Pemilu yang diselenggarakan oleh pemerintah.

\section{Analisis tentang Tingkat Partisipasi Ma- syarakat dalam Menggunakan Hak Suara dalam Pemilu Legislatif 2014 di Keca- matan Godong Kabupaten Grobogan}

Dari hasil pembahasan wawancara diatas dapat dilihat jika masyarakat belum begitu antusias pada Pemilu Legislatif kali ini. Walaupun pemilih yang hadir pada Pileg kali ini meningkat dibandingkan dengan Pilgub kemarin dari hanya 43,05 \% menjadi 69\%, akan tetapi kepedulian masyarakat terhadap terjadi kecurangan-kecurangan yang terjadi pada Pemilu dan hasil pemilu kebanyakan dari mereka tidak peduli dengan hal-hal tersebut.karena menurut mereka yag terpenting adalah telah menggunakan hak suara mereka.

Politik uang sendiri di Kecamatan Godong masih sering terjadi dan masih sangat mempengaruhi pilihan mereka dalam memilih pada pemilu. Bahkan ada masyarakat yang mengharapkan politik uang itu terjadi. Hal itu disebabkan karena faktor ekonomi yang membuat beberapa masyarakat mengharapkan uang dari adanya pemilu. Di sisi lain, politik uang dinilai tidak lagi begitu efektif mempengaruhi pilihan rakyat. Karena rakyat semakin cerdas memanfaatkan peluang ekonomi mereka. Mereka menganggap pemilu adalah ajang mendapatkan uang dengan cuma-cuma. Mereka menerima uang 
dari siapa saja tetapi belum tentu memilih, apalagi memilih yang memberikan uang.

Maka dari itu sosialisasi mengenai pemilu dan sosialisasi tentang politik uang harus sering dilakukan. Selain untuk meningkakan kesadaran hukum masyarakat di kecamatan Godong Kabupaten Grobogan, juga untuk meningkatkan antusiasme masyarakat untuk ikut serta mengawasi pelanggaran-pelanggaran yang terjadi saat Pemilu.

Pada Pemilu Legislatif 2014 kali ini partisipasi dan partisipasi masyarakat Kecamatan Godong dalam menggunakan hak suara sedikit meningkat dibandingkan Pemilu Legislatif sebelumnya yaitu Pemilu Legislatif 2009. Hal ini karena disebabkan lebih banyaknya sosialisasi dari KPU mengenai Pemilu Legislatif, banyaknya iklan-iklan dan acara-acara di televisi yang membahas tentang Pemilu Legislatif kali ini, dan adanya tokoh-tokoh tertentu dari suatu partai yang dikagumi oleh masyarakat yang membuat antusiasme masyarakat meningkat dan membuat minat masyarakat untuk menggunakan hak suaranya pada Pemilu Legislatif 2014 kali ini.

Jadi pengaruh sosialisasi, iklan dan adanya sosok figur yang dikagumi masyarakat sangat berpengaruh terhadap minat masyarakat untuk berpartisipasi dan menggunakan hak suaranya dalam setiap Pemilu. Akan tetapi walaupun ada peningkatan jumlah pemilih yang hadir ke TPS (Tempat Pemungutan Suara), Kecamatan Godong masih menjadi salah satu Kecamatan dengan jumlah golput yang terbesar di Kabupaten Grobogan dengan sebanyak 21.743 pemilih yag tidak hadir.

Adanya tokoh atau sosok yang dikagumi oleh masyarakat dan menjadi calon pemimpin juga dapat meningkatkan partisipasi masyarakat dalam menggunakan hak pilih mereka. Masyarakat lebih antusias jika ada calon pemimpin yang memiliki tujuan yang sama dengan mereka, dan yang masyarakat anggap mampu untuk membuat masyarakat lebih sejahtera. Sesuai dengan Teori pilihan rasional (rational choice) yang memberikan penjelasan untuk memusatkan perhatian pada aktor dimana aktor dipandang sebagai manusia yang mempunyai tujuan atau mempunyai maksud artinya aktor mempunyai tujuan dan tindakan tertuju pada upaya untuk mencapai tujuan tersebut. Secara tidak langsung teori ini telah memandang bahwa manusia politik sudah mengarah pada manusia ekonomi karena setiap individu dalam menentukan pilhannya terhadap aktor tertentu lebih mengedepankan pendekatan ekonomi dalam kegiatan politiknya.

Penulis berpendapat jika ada sosok atau tokoh yang dinilai masyarakat sebagai sosok yang ideal sebagai calon pemimpin dalam pemilu, dapat meningkatkan antusiasme masyarakat untuk menggunakan hak pilih mereka karena mereka berharap jika calon pemimpin tersebut sesuai dengan harapan mereka. Akan tetapi jika masyarakat menilai tidak ada sosok calon pemimpin dalam pemilu yang dianggap ideal sebagai calon pemimpin, masyarakat menjadi enggan untuk menggunakan hak pilih mereka karena tidak sesuai dengan harapan masyarakat.

Selain adanya tokoh yang dikagumi masyarakat pada suatu partai politik, prestasi-prestasi yang didapatkan oleh anggota partai politik itu sendiri juga dapat mempengaruhi pilihan masyarakat. Seperti pada pemilu legislatif 2009, adanya sosok seorang Susilo Bambang Yudhoyono (SBY) pada kubu Partai Demokrat dan yang juga merupakan Ketua Umum Partai Demokrat, membuat Partai Demokrat mendapatkan perolehan suara tertinggi di Kecamatan Godong Kabupaten Grobogan dengan 9.069 suara. Pada saat itu SBY sebagai Presiden Republik Indonesia dianggap mampu menumbuhkan ekonomi Indonesia, dan mampu memimpin Negara Indonesia dengan baik. Hal itu membuat kebanyakan masyarakat Kecamatan Godong Kabupaten Grobogan memilih Partai Demokrat pada Pileg 2009.

Sedangkan pada Pemilu Legislatif 2014 kali ini Parpol yang memperoleh suara terbanyak adalah PDIP dengan 9.822 suara. Hal itu merupakan peningkatan yang cukup signifikan jika dibandingkan dengan Pileg 2009 yang pada saat itu PDIP hanya memperoleh sebesar 5.383 suara di Kecamatan Godong Kabupaten Grobogan. Peningkatan perolehan suara ini tidak lepas dari prestasi-prestasi dari beberapa anggota partainya, seperti adanya sosok Jokowi yang pada saat itu menjabat sebagai Gubernur DKI Jakarta, Ganjar 
Pranowo sebagai Gubernur Jawa Tengah dan Ibu Risma sebagai Wali Kota Surabaya dimana tokoh-tokoh tersebut dianggap mampu mempin daerahnya masing-masing dengan sangat baik dan dianggap mampu memajukan daerah-daerah mereka pimpin. Prestasiprestasi tersebut membuat perolehan suara PDIP pada Pileg 2014 di Kecamatan Godong Kabupaten Grobogan kali ini meningkat dan bahkan mendapatkan perolehan suara terbanyak.

Sedangkan perolehan suara Partai Demokrat pada Pileg 2014 di Kecamatan Godong Kabupaten Grobogan kali ini mengalami penurunan. Jika dibandingkan pada Pileg 2009 dimana Partai Demokrat memperoleh 9069 suara, pada Pileg 2014 kali ini Partai Demokrat hanya memperoleh 3.682 suara. Hal itu disebabkan karena adanya beberapa petinggi partai yang terseret kasus korupsi, dan banyaknya berita-berita yang didapatkan oleh Partai Demokrat baik dari media cetak maupun media elektronik. Hal tersebut membuat kepercayaan masyarakat pada Partai Demokrat menjadi berkurang sehingga menyebabkan perolehan suara Partai Demokrat turun secara signifikan.

Hal-hal tersebut menunjukan bahwa masyarakat Kecamatan Godong Kabupaten Grobogan semakin cerdas dalam memilih Partai Politik. Masyarakat memilih suatu Partai Politik bukan karena rasa cintanya kepada suatu Parpol, akan tetapi masyarakat melihat pada prestasi-prestasi dan kinerjakinerja yang dilakukan oleh anggotaanggota Parpol dalam melaksanakan tugastugasnya.

\section{Analisis tentang Alasan Masyarakat Ke- camatan Godong Kabupaten Grobogan Melakukan Golput dan Solusinya.}

Golput atau golongan putih adalah kelompok-kelompok yang tidak menggunakan hak pilihnya untuk berpartisipasi dan mensukseskan Pemilu. Ada berbagai pendapat tentang fenomena golput ini. Ada yang beranggapan bahwa golput itu adalah hak asasi manusia yang membuat para pemegang hak pilih untuk bebas menggunakan hak pilihnya atau tidak, dan ada juga yag berpendapat bahwa Golput adalah suatu tindakan yang mencederai demokrasi karena tidak ikut mensukseskan Pemilu yang telah diselenggarakan oleh Negara.

Tentang bagaimanapun pendapat masyarakat mengenai golput, hal ini telah menjadi fenomena yang selalu terjadi pada setiap Pemilu. Hal tersebut disebabkan oleh berbagai hal yag menyebabkan masyarakat tidak menggunakan hak pilihnya pada penyelenggaraan Pemilu.

Pada Pemilu Legislatif yang telah dilaksanakan pada tanggal 9 April 2014 lalu, fenomena Golput juga masih terjadi. Dengan berbagai macam-macam faktor yang menyebabkan tingginya angka golput. Di Kecamatan Godong Kabupaten Grobogan sendiri dari sebesar 66.378 pemilih, ada sebanyak 45.564 (69\%) pemilih yang hadir, sementara pemilih yang tidak hadir sebanyak 21.743 (31\%) pemilih yang tidak hadir.

Dari hasil penelitian yang dilakukan oleh penulis, ada beberapa penyebab mengapa masyarakat di Kecamatan Godong Kabupaten Grobogan melakukan Golput pada Pemilu Legislatif kali ini. Berikut adalah penyebab-penyebab mengapa masyarakat melakukan Golput:

Pertama, tidak tertariknya masyarakat dengan pemilu. Dari hasil penelitian penelitian Penulis ditemukan bahwa salah satu penyebab masyarakat Kecamatan Godong melakukan Golput adalah tidak tertariknya atau tidak pedulinya masyarakat dengan politik. Masyarakat beranggapan bahwa dengan adanya Pemilu dan siapa saja yang kelak akan menjadi pemimpin tidak akan berpengaruh pada kehidupan mereka, dan tidak percayanya mereka pada calon-calon anggota legislatif yang mencalonkan diri pada Pemilu Legislatif 2014 kali ini.

Kedua, tingkat masyarakat urban yang tinggi. Tingginya angka masyarakat urban di Kecamatan Godong Kabupaten Grobogan menjadi salah satu faktor penyebab tingginya angka Golput. Menurut Bapak Sarsono sebagai ketua PPK Kecamatan Godong, salah satu faktor warga memilih untuk tidak hadir pada Pemilu dikarenakan banyak warga yang menjadi perantau. Baik merantau keluar kota maupun menjadi TKI diluar negeri. Dan me- 
nurut Bapak Ir. Jati Purnomo. Msi sebagai Divisi Sosialisasi KPU Grobogan sekitar 25\%$30 \%$ pemilih tidak berada ditempat. Mereka merantau untuk bekerja maupun untuk kuliah di luar kota. Dan kebanyakan warga yang sedang merantau di luar kota enggan untuk pulang pada saat Pemilu untuk menggunakan hak pilihnya.

Karena banyak dari mereka yang yang tidak bisa meninggalkan pekerjaannya dan mereka enggan untuk mengeluarkan biaya untuk transportasi yang mahal untuk mengikuti Pemilu di kampung halaman mereka. Selain itu rumitnya prosedur administrasi pindah memilih membuat masyarakat yang merantau ke luar kota enggan untuk mengurusnya, karena mereka kebanyakan tidak bisa meninggalkan pekerjaan mereka untuk mengurus prosedur administrasi pindah memilih tersebut. Masyarakat tidak ingin meninggalkan pekerjaannya untuk mengurus prosedur administrasi pindah memilih yang dianggap berbelit-belit untuk mengikuti Pemilu.

Ketiga, tidak menemukan calon legislatif yang sesuai. Tidak adanya calon yang sesuai dengan kriteria yang di harapkan oleh masyarakat juga menjadi salah satu faktor yang menyebabkan masyarakat enggan untuk menggunakan hak pilihnya. Karena dari pemimpin-pemimpin sebelumnya yang dinilai tidak memberikan begitu banyak perubahan membuat kriteria masyarakat terhadap pemimpin selanjutnya menjadi tinggi, dan yang dianggap bisa memberikan perubahan untuk daerah mereka. Dan dengan tidak adanya calon yang sesuai dengan kriteria mereka membuat mereka enggan untuk menggunakan hak pilih mereka karena dianggap calon pemimpin yang baru tidak akan lebih baik dan tidak akan memberikan yang perubahan baik.

Partisipasi politik adalah kegiatan seseorang atau sekelompok orang untuk ikut serta secara aktif dalam kehidupan politik yaitu dengan jalan memilih pimpinan $\mathrm{Ne}$ gara dan secara langsung atau tidak langsung mempengaruhi kebijakan pemerintah. Kemudian dijelaskan pula bahwa kegiatan ini mencakup tindakan seperti memberikan suara dalam pemilihan umum, menhadiri rapat umum, menjadi aggota suatu partai atau kelompok kepentingan, mengadakan hubungan denan pejabat pemerintahan atau anggota parlemen dan sebagainya (Budiarjo, 1998).

Seperti yang telah dijelaskan diatas, partisipasi politik masyarakat Kecamatan Godong Kabupaten Grobogan sendiri mendapatkan beberapa faktor yang menghambat masyarakat untuk berpartisipasi dalam politik. Seperti, faktor ekonomi yang membuat masyarakat harus mencari pekerjaan di luar kota untuk dapat memenuhi kebutuhan ekonominya. Hal itu membuat masyarakat yang bekerja di luar kota kesulitan untuk ikut berpartisipasi dalam pemilu, karena sebagian besar dari mereka masih terdaftar sebagai DPT (Daftar Pemilih Tetap) di daerah asalnya yaitu Kecamatan Godong Kabupaten Grobogan, dan rumitnya prosedur dalam pindah memilih juga membuat masyarakat urban kesulitan dalam mengurus proses pindah memilih tersebut.

Dalam meningkatkan minat masyarakat terhadap pemilu juga harus sering diadakan sosialisasi. Karena jika semakin banyak sosialisasi, maka tingkat ketertarikan masyarakat juga akan semakin bertambah. Karena masih banyak masyarakat yang berpendapat bahwa politik itu tidak ada yang bersih dan jujur dan hal itu membuat masyarakat enggan menggunakan hak pilih mereka karena menganggap siapapun yang akan menjadi pemimpin, hasilnya tidak akan berbeda.

Dari hasil penelitian penulis, disini penulis berpendapat bahwa seharusnya pemerintah harus lebih banyak melakukan sosialisasi untuk meningkatkan antusiasme dan juga meningkatkan kesadaran masyarakat untuk mau menggunakan hak pilih mereka pada setiap penyelenggaraan Pemilu. Selain itu pemerintah juga harus mempermudah proses pindah memilih. Agar warga yang merantau ke luar kota ataupun ke luar negeri tetap bisa menggunakan hak pilih mereka tanpa harus pulang ke kampong halaman mereka. Dan pemerintah harus mampu menyelenggarakan Pemilu yang ideal, yang diikuti oleh Parpol yang kredibel, penyelenggara yang berintegritas dan netral dan membuat masyarakat menjadi lebih cerdas untuk menggunakan hak pilih mereka. 
Dalam meningkatkan partisipasi masyarakat dalam menggunakan hak pilih masyarakat Kecamatan Godong Kabupaten Grobogan, KPU Kabupaten Grobogan juga melakukan upaya-upaya untuk meningkatkan partisipasi masyarakat dengan mengadakan sosialisasi dengan tokoh ulama dan tokoh masyarakat agar mengajak masyarakat untuk menggunakan hak pilih mereka. KPU Kabupaten Grobogan juga mengadakan siaran keliling ke daerah-daerah di Kabupaten Grobogan, melakukan penyebaran spanduk dan stiker di masing-masing Desa, membuat iklan tentang pemilu di radio-radio maupun media cetak yang ada di Kabupaten Grobogan. Selain itu KPU Kabupaten Grobogan juga melakukan kerjasama dengan Pemda untuk pemilih daerah di tingkat Kecamatan.

\section{Analisis tentang Ketentuan Hukum Men- genai Golput}

Pilihan untuk golput merupakan HAM bagi setiap warga Negara. Oleh karena itu tidak ada yang dapat memaksakan seseorang untuk harus memilih pada Pemilu. Pada pasal 28 E UUD 1945 menjelaskan bahwa "Pemilihan umum dilaksanakan secara langsung, umum, bebas, rahasia, jujur, dan adil setiap lima tahun sekali". Kata "bebas" pada pasal tersebut berarti masyarakat bebas untuk memilih maupun tidak memilih pada penyelenggaraan Pemilu.

Akan tetapi bukan berarti Pemerintah sebagai penyelenggara Pemilu boleh lepas tangan dengan permasalahan golput. Pemerintah juga harus berupaya untuk menangani angka golput ini agar Penyelenggaraan Pemilu dapat berjalan baik. Karena sesungguhnya Pemilu adalah pesta demokrasi bagi masyarakat, sehingga jika masyarakat yang memilih untuk golput maka masyarakat telah merusak demokrasi itu sendiri karena membuat jalannya pesta demokrasi tidak berjalan dengan baik.

Penyebab golput tidak hanya disebabkan dari kepedulian masyarakat terhadap Pemilu itu rendah dan kehendak masyarakat. Tetapi golput juga disebabkan karena adanya masyarakat yang tidak terdaftar sebagai daftar pemilih tetap (DPT) yang membuat masyarakat tidak dapat menggunakan hak suaranya pada saat Pemilu. Hal tersebut juga bisa disebut sebagai pelanggaran HAM, karena telah menghilangkan hak politik dan hak konstitusi warga Negara untuk menggunakan hak suaranya pada Pemilu.

\section{Simpulan}

Berdasarkan hasil penelitian dan pembahasan yang telah diuraikan pada bab sebelumnya maka penulis dapat menyimpulkan sebagai berikut. Pertama, tingkat partisipasi masyarakat pada Pemilu Legislatif 2014 kali ini meningkat. Karena jika dibandingkan dengan Pemilu Legislaif 2009, pemilih yang hadir meningkat walaupun jumlah peningkatannya bisa dibilang sedikit. Dan walaupun sebenarnya tingkat masyarakat yang golput masih cukup banyak. Dari data yang penulis peroleh, dari sebesar 66.378 pemilih, ada sebanyak 45.564 (69\%) pemilih yang hadir, sementara sebanyak 21.743 (31\%) pemilih yang tidak hadir.

Kedua, tingginya angka masyarakat urban di Kecamatan Godong Kabupaten Grobogan menjadi salah satu penyebab banyaknya pemegang hak pilih yang golput, sekitar 25\%-30\% pemegang hak pilih tidak berada ditempat atau berada di luar kota, baik untuk bekerja maupun kuliah dan lain-lain. Tidak tertariknya masyarakat Kecamatan Godong Kabupaten Grobogan dengan Pemilu juga menjadi penyebab mengapa masyarakat memilih untuk golput. Dan juga banyak masyarakat yang tidak mengetahui tentang sosok calon-calon legislatif yang akan dipilih juga menyebabkan masyarakat enggan untuk menggunakan hak pilihnya.

Ketiga, jika dilihat dari pasal 28 E UUD 1945, golput bukanlah sebuah pelanggaran hukum melainkan HAM. Jadi masyarakat bebas untuk memilih ataupun tidak memilih pada penyelenggaraan Pemilu. Masyarakat yang tidak dapat memilih karena tidak terdatar sebagai DPT (Daftar Pemilih Tetap) merupakan suatu pelanggaran HAM, karena telah 
menghilangkan hak politik sebagai warga $\mathrm{Ne}$ gara yang berhak untuk memilih

Atas dasar hal-hal tersebut, penulis menyarankan beberapa hal. Pertama, pemerintah perlu lebih mempermudah proses pindah memilih, agar masyarakat yang merantau ke luar kota maupun keluar negeri dapat dengan mudah mendapatkan hak pilih, dan tetap bisa berpartisipasi menggunakan hak pilihnya tanpa harus pulang ke kampong halamannya terlebih dahulu. Selanjutnya, KPU harus lebih meningkatkan sosialisasi, agar antusiasme masyarakat terhadap Pemilu menjadi meningkat, dan agara masyarakat mau untuk dating ke TPS untuk menggunakan hak pilih mereka. Yang terakhir, Bawaslu seharusnya cepat untuk menanggapi laporan-laporan dari warga, tidak hanya membiarkannya saja. Dan Bawaslu juga harus lebih sering turun langsung ke lapangan untuk meningkatkan pengawasan terhadap jalannya Pemilu.

\section{Daftar Pustaka}

Adi, Rianto. 2010. Metodologi Penelitian Sosial dan Hukum. Jakarta : Granit.

Amiruddin dan Asikin, Zainal. 2003. Pengantar Metode Penelitian Hukum. Jakarta : PT. Raya Grasindo Persada.

Arikunto, Suharsimi. 2006. Prosedur Penelitian. Yogyakarta : Reneka Cipta.

Budiarjo, Miriam. 1998. Partisipasi dan Partai Politik. Jakarta: Yayasan Obor.

M. Gaffar, Janedjri. 2012. Politik Hukum Pemilu. Jakarta: Konstitusi Press.

Mardalis. 2010. Metode Penelitian Suatu Pendekatan Proposal. Jakarta : Bumi Aksara.

Moleong, Lexy J. 2007. Metodolagi Penelitian Kualitatif. Bandung: PT Remaja Rosdakarya.

Marzuki. 2002. Metodologi Riset. Yogyakarta : UII Press. Sastroatmodjo, Sudijono. 1995. Perilaku Politik. Semarang: IKIP Semarang Press.

\section{Undang-undang :}

Undang-undang Dasar Negara Republik Indonesia Tahun 1945.

Undang-Undang Nomor 32 Tahun 2004 Tentang Pemerintah Daerah.

Undang-Undang No. 22 Tahun 2007 Tentang Penyelenggaraan Pemilihan Umum.
Arianto, Bismar. 2011. "Analisis Penyebab Masyarakat Tidak Memilih dalam Pemilu". Jurnal Ilmu Politik dan Ilmu Pemerintahan, Vol. I, No. 1.

Subanda, Nyoman. 2009. "Analisis Kritis Terhadap Fenomena Golput dalam Pemilu". Jurnal Konstitusi, Vol. II, No. 1.

Jurnal : 